\title{
ANCHORAGE OF REINFORCEMENT BARS IN HENNEBIQUE R.C. STRUCTURES
}

\author{
A. BRENCICH ${ }^{*}$, M. NEBIACOLOMBO ${ }^{2}$ \\ ${ }^{1}$ Department of Civil, Chemical and Environmental Eng.ng (DICCA) \\ University of Genoa - Polytechnic School \\ viale Cambiaso 1 - 16145 Genova (Italy) \\ e-mail: brencich@dicca.unige.it, www.dicca.unige.it (*corresponding author) \\ ${ }^{2}$ Department of Civil, Chemical and Environmental Eng.ng (DICCA) \\ University of Genoa - Polytechnic School \\ viale Cambiaso 1 - 16145 Genova (Italy) \\ e-mail: matteo.nebiacolombo@outlook.it
}

Keywords: Hennebique-type structure, Anchorage, Collapse Mechanism

\begin{abstract}
The Hennebique system was the most successful among the patented systems in the pre-code period even though the design rules were not completely clear. Anchorage of the reinforcement is one of these unknown aspects and how it was calculated, and if it was calculated at all, is still today not clear. For this reason, the efficiency of the anchorages is one of the major issues when dealing with retrofitting a Hennebique structure or when its safety needs to be evaluated. In this paper a series of tests have been performed on the typical Hennebique an-chorages for reinforcing bars (fish-tails) and for the plate stirrups (bended ends) that were used. Different concrete types have been used so that either the collapse mechanisms of the anchor-ages and their ultimate strength may be identified.
\end{abstract}

\section{INTRODUCTION}

Even though François Hennebique was not the first to deal with concrete and reinforcing bars, no doubt he was one of those who most affected the first years of reinforced concrete constructions [1-4]. His patent, although unclear in its theoretical basis and in several technological aspects, in many countries was the most exploited system in the first pioneering period of r.c. constructions [5-7] that ends approx. with WWI [8]. If the Hennebique system did not find space in Germany [9], it was used in U.K. due to the cooperation with Mouchel [5] and in Spain with Rivera [10] while in other countries, such as France [11], Belgium [4] and Italy [1114] it remained the leading building system for a couple of decades.

Even though the first codes in Europe were issued before WWI, in 1902 for Switzerland, in 1907 for Italy and France [15] and in 1915 for Russia [16], it took more than a decade for the patent system to be substituted by a rational approach to r.c. design. This is mainly true for those countries in which the patents remained valid till their natural expiration, such as Italy and Spain. The outcome is that Hennebique structures, or Hennebique-like structures, built till approx. the '20s, remained un-engineered to a large extent. 
Nowadays warehouses, industrial facilities, a large number of bridges and buildings, either residential and public, built according to the Hennebique system, are in service. For many of them retrofitting is needed due to several reasons, such as material degradation, re-functioning and, mainly for strategic buildings such as schools, hospitals and public offices, for their seismic upgrade.

The intrinsic weaknesses of the early reinforced concrete structures, among which the Hennebique system plays the major role, is well known and addressed by several authors [4, 17-22]. The two main issues need specific attention: i) concrete compressive strength, affecting the bending capacity of the beams; ii) shear capacity, which depends on the amount of shear reinforcement and on the efficiency of its anchorage.

This paper addresses a specific problem: the anchorage performance of either bending and shear reinforcing bars. Due to the reduced anchorage length, only partially compensated by the shape of the bar, it will be showed that in most cases the bending and shear capacity is limited by the sliding of the bars in the anchorage regions. This outcome is crucial when the structural performance of a Hennebique-type structure has to be estimated.

\section{ANCHORAGE OF REINFORCING BARS IN THE HENNEBIQUE SYSTEM}

Figures 1 to 3 show the typical reinforcement of a Hennebique beam.

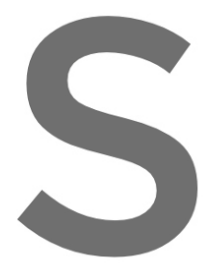

$50 \%$ of the longitudinal reinforcement (cylindrical bars from $10 \mathrm{~mm}$ to $40 \mathrm{~mm}$ in diameter) is bended up at 1/3 of the span, figure 1, [7] and [24], and anchored on the upper side by means of fish-tail expansions. Such a rule is simply geometric and in the archives there is no rational reason for such a choice; the upper bars, therefore, are not propprtioned to the ne ative bending monent
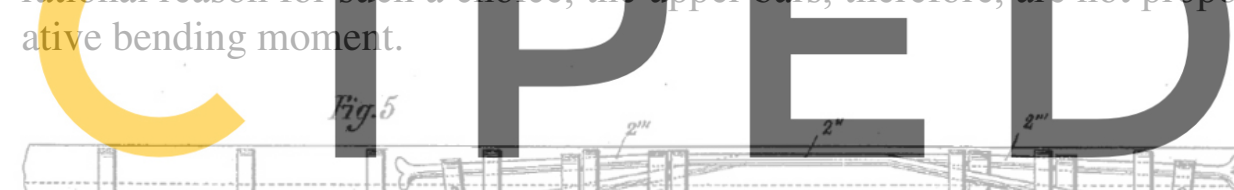

$=$

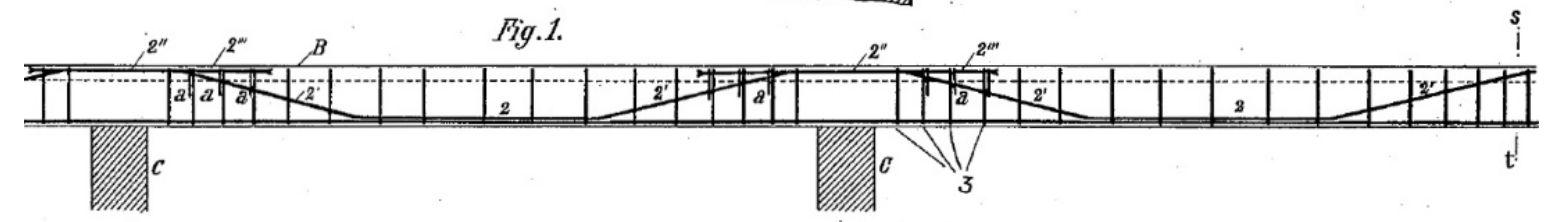

Figure 1. Longitudinal section of a beam according to the USA Hennebique patent [27]

- the anchorage of the main bars consists of fish-tail ends; hooks were used for secondary bars only, figure 2. The fish tails were open as much as to get to twice diameter of the bar. Amongst the large number of load tests to collapse performed by Hennebique and his concessionaries, some showed the collapse of the anchorage of the longitudinal bars, figure 3; there is no evidence that this outcome of the test neither lead to some change in the detailing of the bars nor raised attention on the bar anchorage. 


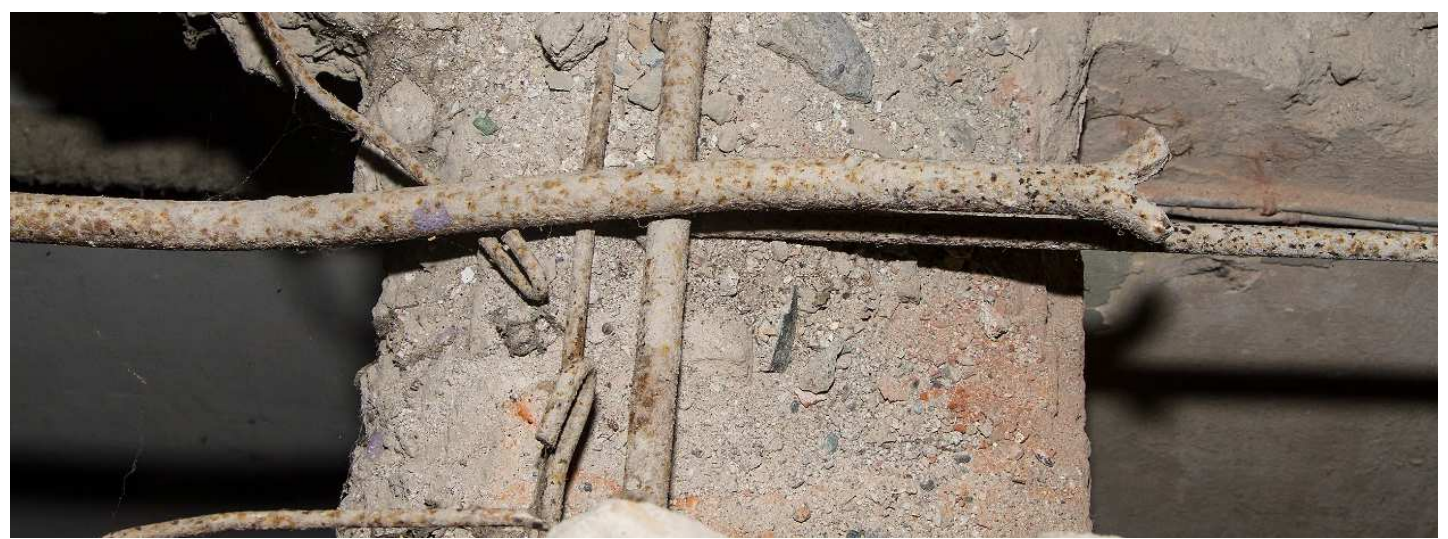

Figure 2. Fish-tail ends and hooks of reinforcing bar of the slab of a villa inside the Villa Gruber park, Genoa, unknown building date, in-between 1900 to 1930.

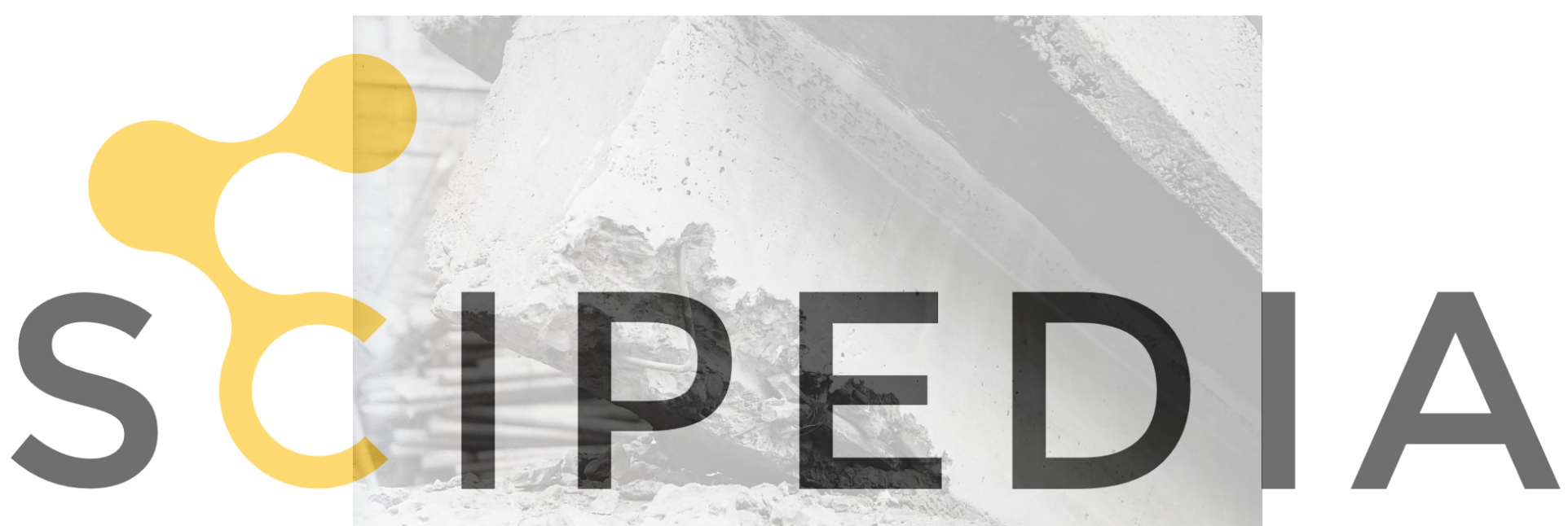

Register for free at https//www.scipedia.com to download the version without the watermark

Figure 3. Load test to collapse of a T beam performed by the Porcheddu company [24] - unpublished photo

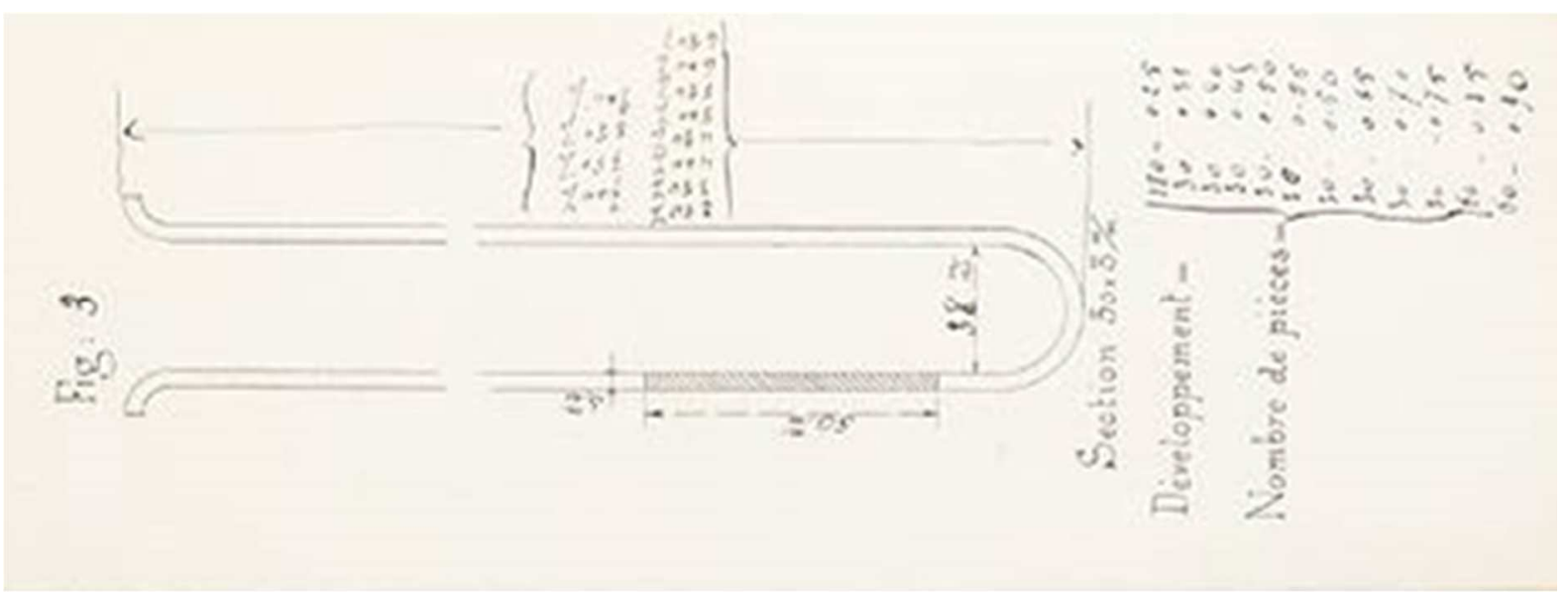

Figure 4. Typical shape of a stirrup, 1897 [28] 
- The shear reinforcement consists of steel plates, 2-to-3 mm thick, 20-to-50mm wide, figure 4. The spacing of the stirrups, figure 1, was geometrical with minimum spacing close to the supports. There's no explicit origin of such a choice, that is somehow rational, that probably originates from the load tests that Hennebique in his company and his concessionaries performed up to collapse. The anchorage of the stirrups is obtained by means of a slight bend of the plate in the compressed part of the beam; also in this case the efficiency of such an anchorage system is to be discussed.

\section{THE EXPERIMENTAL PROGRAM}

The goals of the research are the identification of the anchorage mechanisms up to collapse, either for longitudinal bars (bending) and for stirrups (shear), taking into account different concrete compressive strength and a grading curve that resembles an ancient pre-code concrete.

\subsection{Concrete mixtures}

An historical concrete differs from modern concretes because of: i) improper mixture (not following any grading curve); ii) round aggregates; iii) excess in water content; iv) low strength (in general, mainly for residential buildings. Industrial facilities and bridges usually exhibit medium-to-high strength concrete).
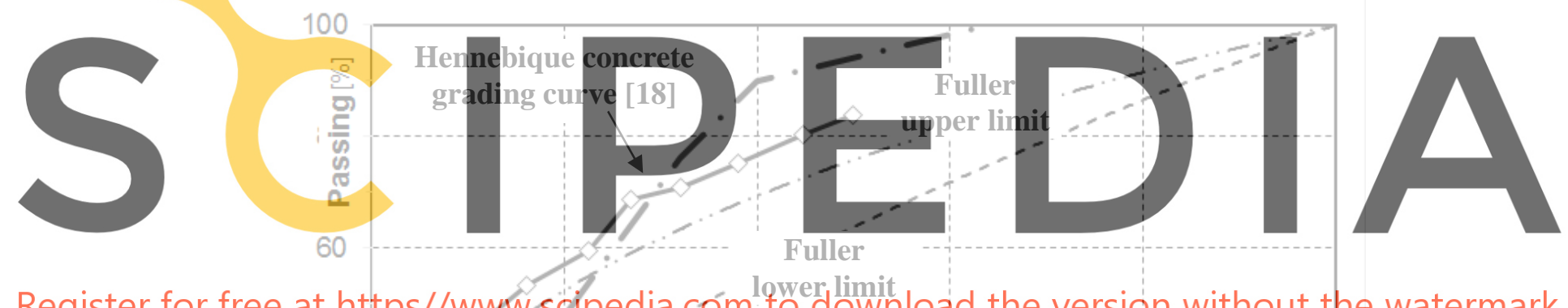

Register for free at https//wyrw.selpedia.cóm lower llimit ownload the version without the watermark

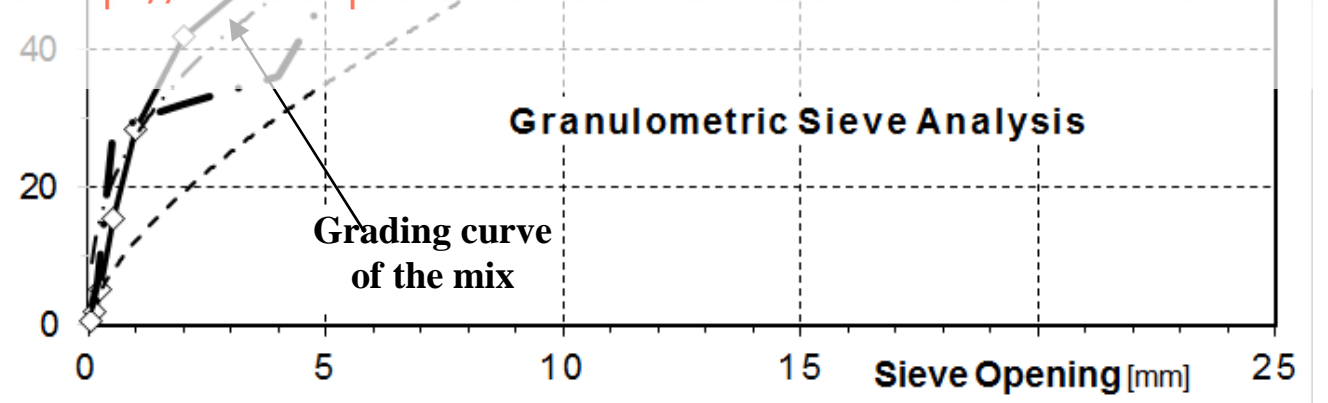

Figure 5. Granulometric sieve curve of the historical-like concrete used compared with the limit Fuller curves

The concrete mixture used for the concrete of the tests was defined according to a weight criterion, like the standard building practice in the past: $50 \mathrm{~kg}$ of round coarse aggregate (max $\phi$ $=30 \mathrm{~mm})+50 \mathrm{~kg}$ of crashed medium aggregates $(\max \phi=15 \mathrm{~mm})+25 \mathrm{~kg}$ of crashed fine aggregates $(\max \phi=3 \mathrm{~mm})+25 \mathrm{~kg}$ of sand $(\max \phi=0.5 \mathrm{~mm})$.

Figure 5 shows the granulometric Fuller sieve curve [31] for the aggregates used and the grading curve deduced for a Hennebique concrete obtained in [18]; it can be seen that pre-code 
concretes, and the one used in the tests, exhibit grading curves above the upper Fuller curve, nowadays used for aggregate proportioning.

Five concrete types were used, table 1, aiming at setting a mix that includes the main defects of historical concrete, such as high porosity and severe bleeding. The first four types, for which in figure 11 the maturation curves are represented (either EC2 curves [31] and the best-fitting ones, curing conditions of the specimens as in [32-33]) were used for estimating the strength of the anchorage, whilst the fifth concrete was used for estimating the effect of transversal confinement on the anchorage strength.

Table 1. Concrete strength and mixtures for the 5 ancient-type concrete

\begin{tabular}{ccccccc}
\hline $\begin{array}{c}\text { Concrete } \\
\text { mix }\end{array}$ & $\begin{array}{c}\text { Cement } \\
{\left[\mathrm{kN} / \mathbf{m}^{\mathbf{3}}\right]}\end{array}$ & $\begin{array}{c}\text { Cement } \\
\text { /batch }[\mathrm{kg}]\end{array}$ & $\begin{array}{c}\text { Water/Cement } \\
\text { ratio }\end{array}$ & $\begin{array}{c}\text { Porosity } \\
{[\mathbf{\%}]}\end{array}$ & $\mathbf{R}_{\mathbf{c}, 28 \text { days }}$ & $\begin{array}{c}\text { C.o.V. [\%] } \\
\text { (6 samples) }\end{array}$ \\
\hline Mix_1 & 2.0 & 18.2 & 1.0 & 8.3 & 8.4 & 3.2 \\
\hline Mix_2 & 3.0 & 27.3 & 0.8 & 8.6 & 14.5 & 2.2 \\
\hline Mix_3 & 4.2 & 38.3 & 0.6 & 8.3 & 25.8 & 2.8 \\
\hline Mix_4 & 5.0 & 45.5 & 0.5 & 7.3 & 29.9 & 0.5 \\
\hline Mix_5 & 3.0 & 27.3 & 0.8 & 8.3 & 20.2 & 3.0 \\
\hline
\end{tabular}

\subsection{Specimens and loadling conditions}
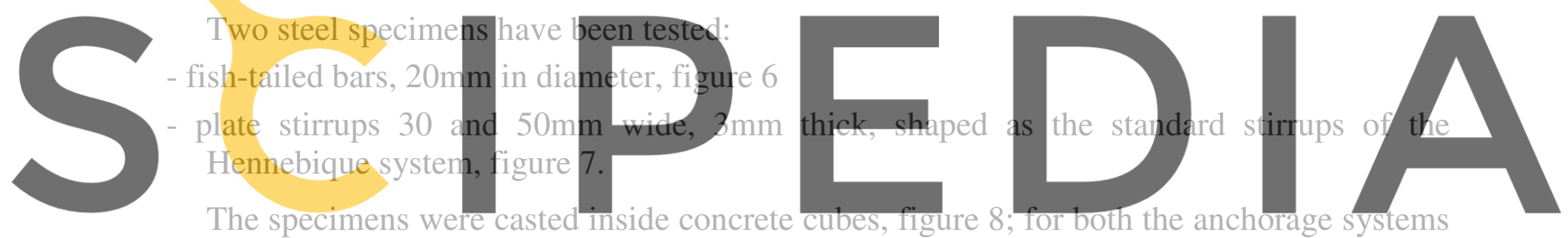

the four concrete types of table 1 were used using standard curing conditions.([32] and [33]).

Register for free at https//www.scipedia.com to download the version without the watermark

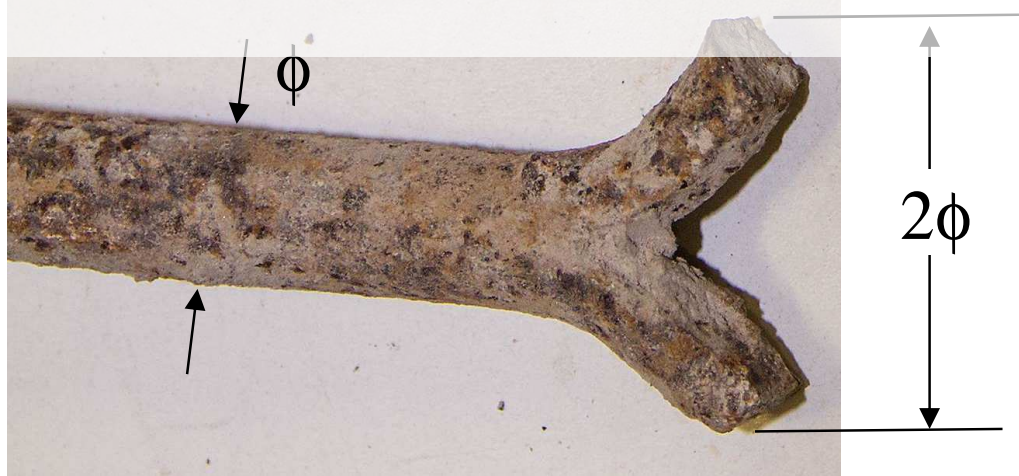

Figure 6: Fish-tailed anchorage of bending reinforcement. From a residential building in Genoa, Villa Grüber park, Genoa, Porcheddu Building Company, in-between 1920-to-1930. main geometric ratios.

The load test was displacement-controlled in order to get also the post-peak response of the anchorage. The load was measured by means of a CLASS 1 load cell (error less then $0.1 \%$ ) and the displacement by means of digital transducers with an error less than $0.01 \mathrm{~mm}$. The loading rate was $3 \mathrm{~mm} /$ minute so that the peak load was reached, on the average, after 3 minutes. 
The lateral confinement was provided by means of bolts and stiff distributing steel devices, figure 8 , which applied a lateral average compressive stress $\sigma_{1}$ and $\sigma_{2}$ of $0.75 \mathrm{~N} / \mathrm{mm}^{2}$.

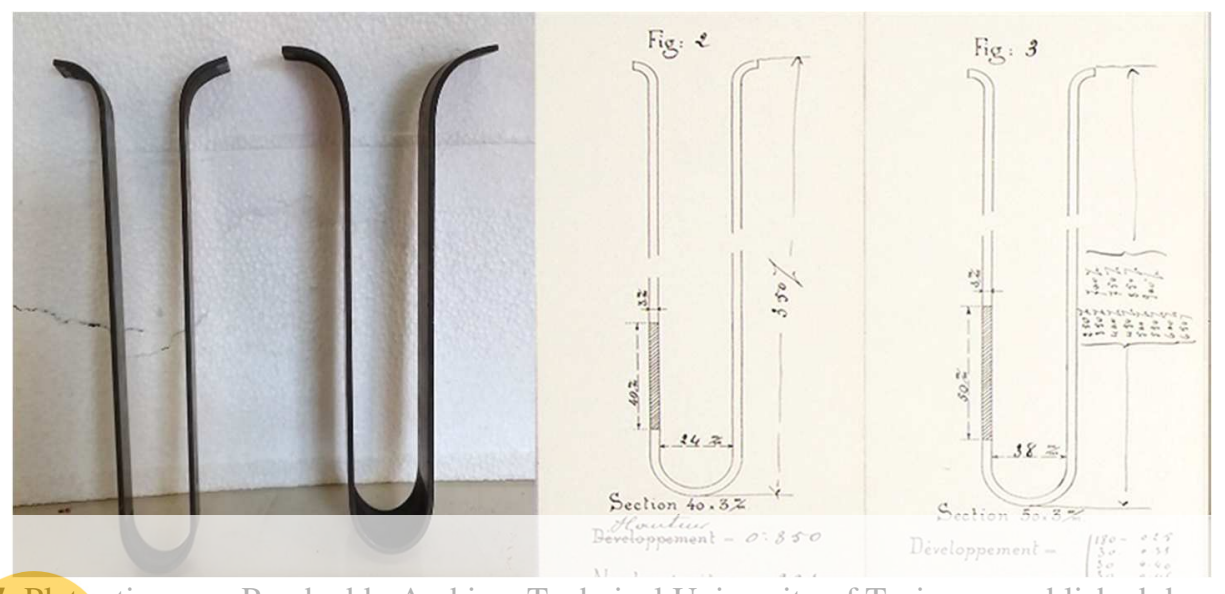

Figure 7: Plate stirrups - Porcheddu Archive, Technical University of Turin - unpublished drawings.
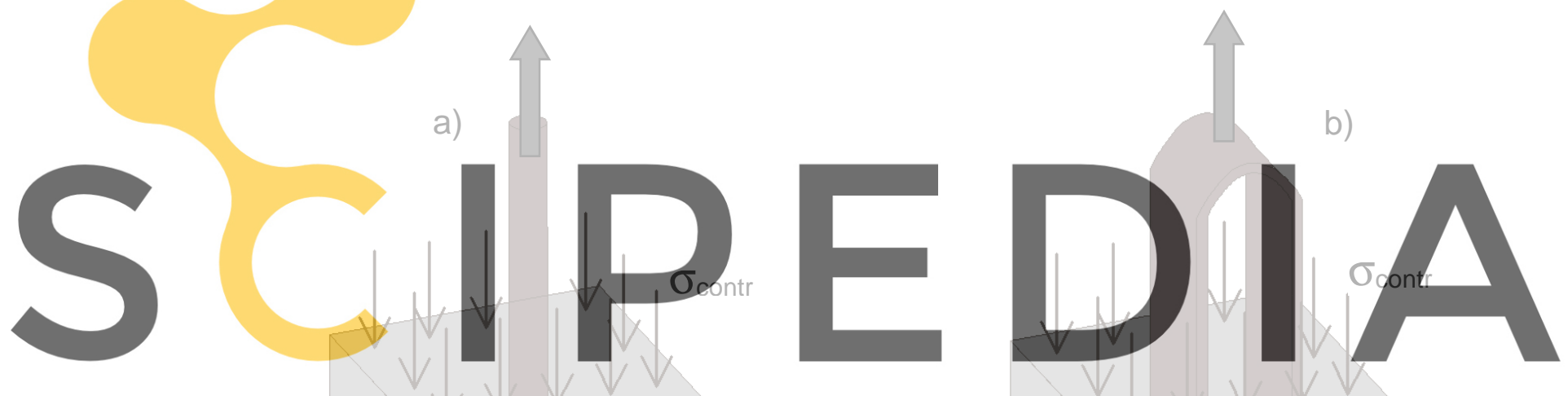

Register for free at https//www.scipedia.com to download the version without the watermark
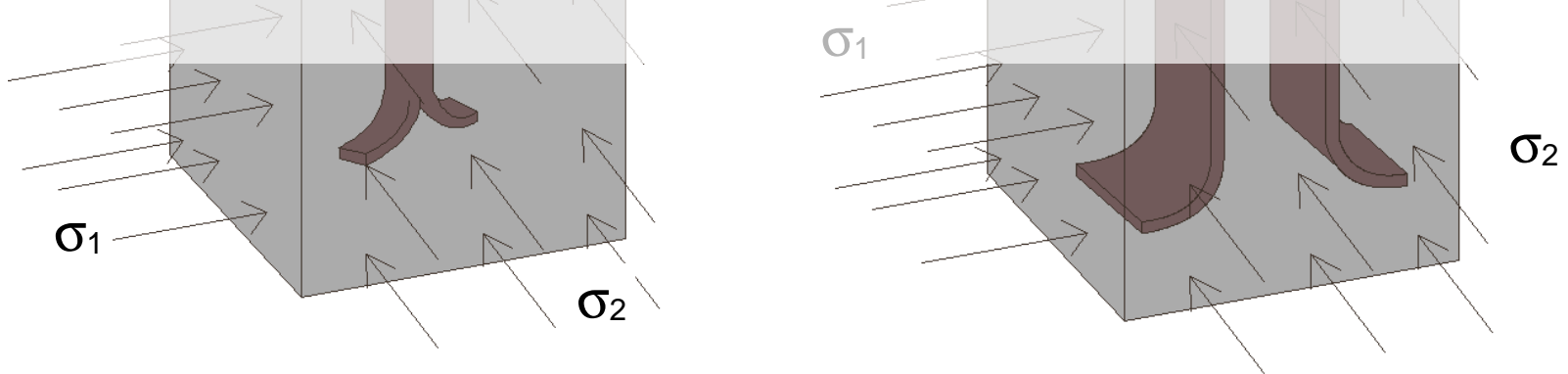

Figure 8: Tested specimens casted in the concrete cube.

\section{TEST RESULTS}

\subsection{Test results}

Figures 9-to-11 show the load-displacement response of the three different specimens for the four concrete types tested. Figure 12 shows the average load-displacement curve, i.e. plotting a curve that is the average out of the 5 diagrams of the previous figure. 

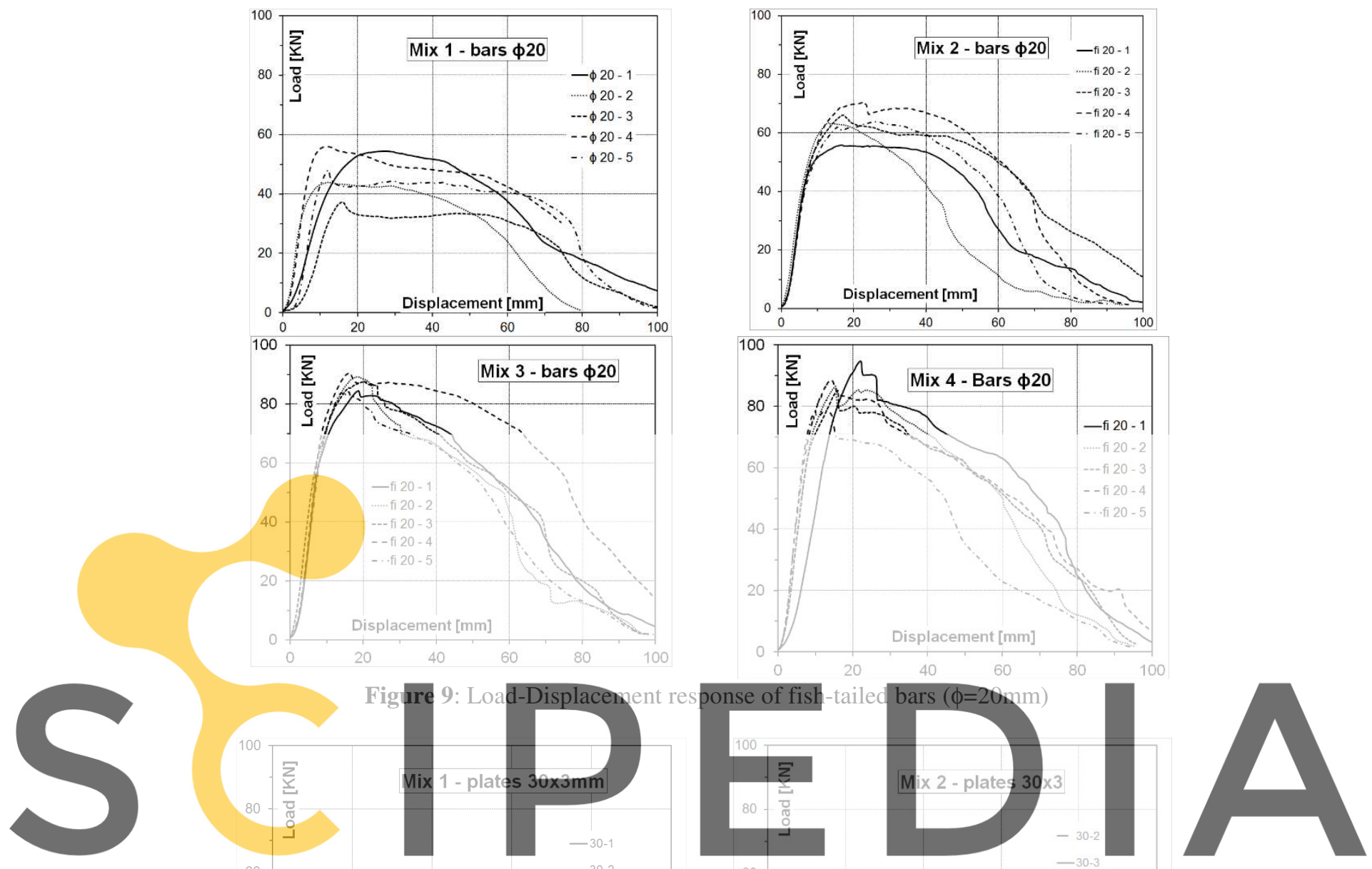

Register for free at https//www.scipedia:com to download the version without the watermark
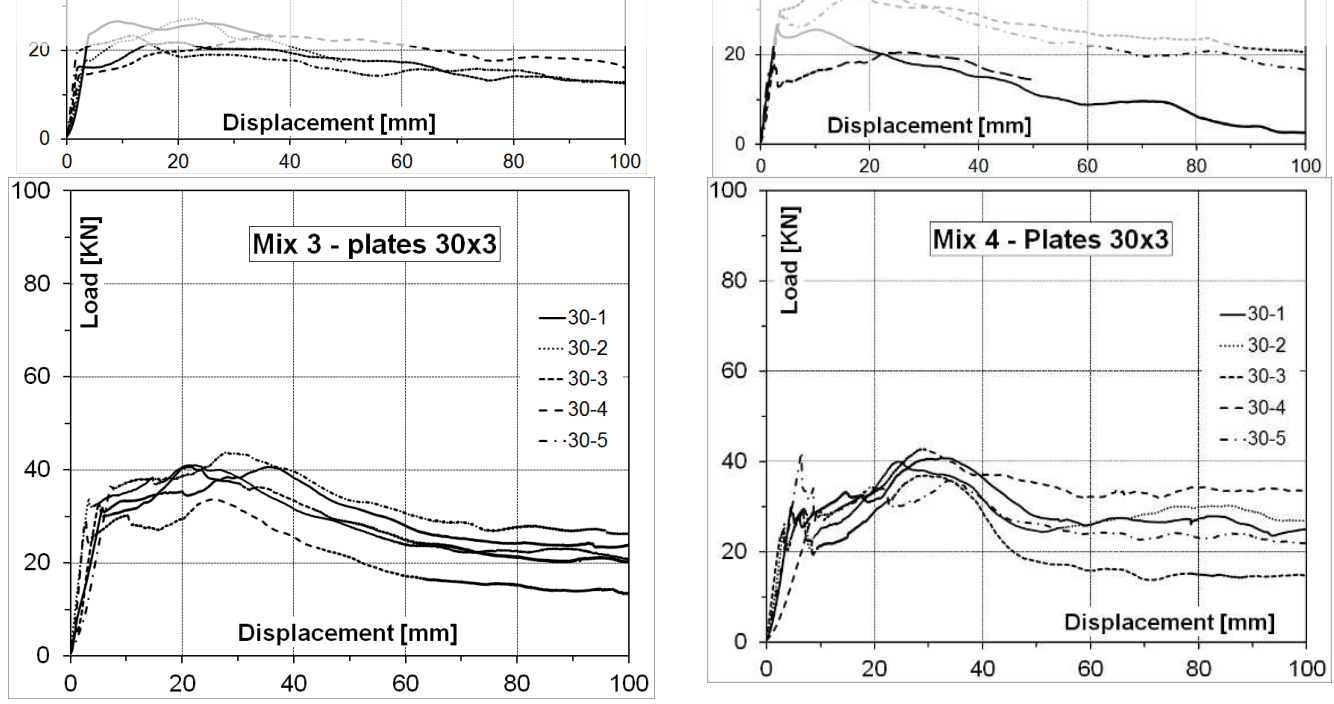

Figure 10 Load-Displacement response of $\underline{30 \mathrm{~mm} \text { wide }}$ plate stirrups 

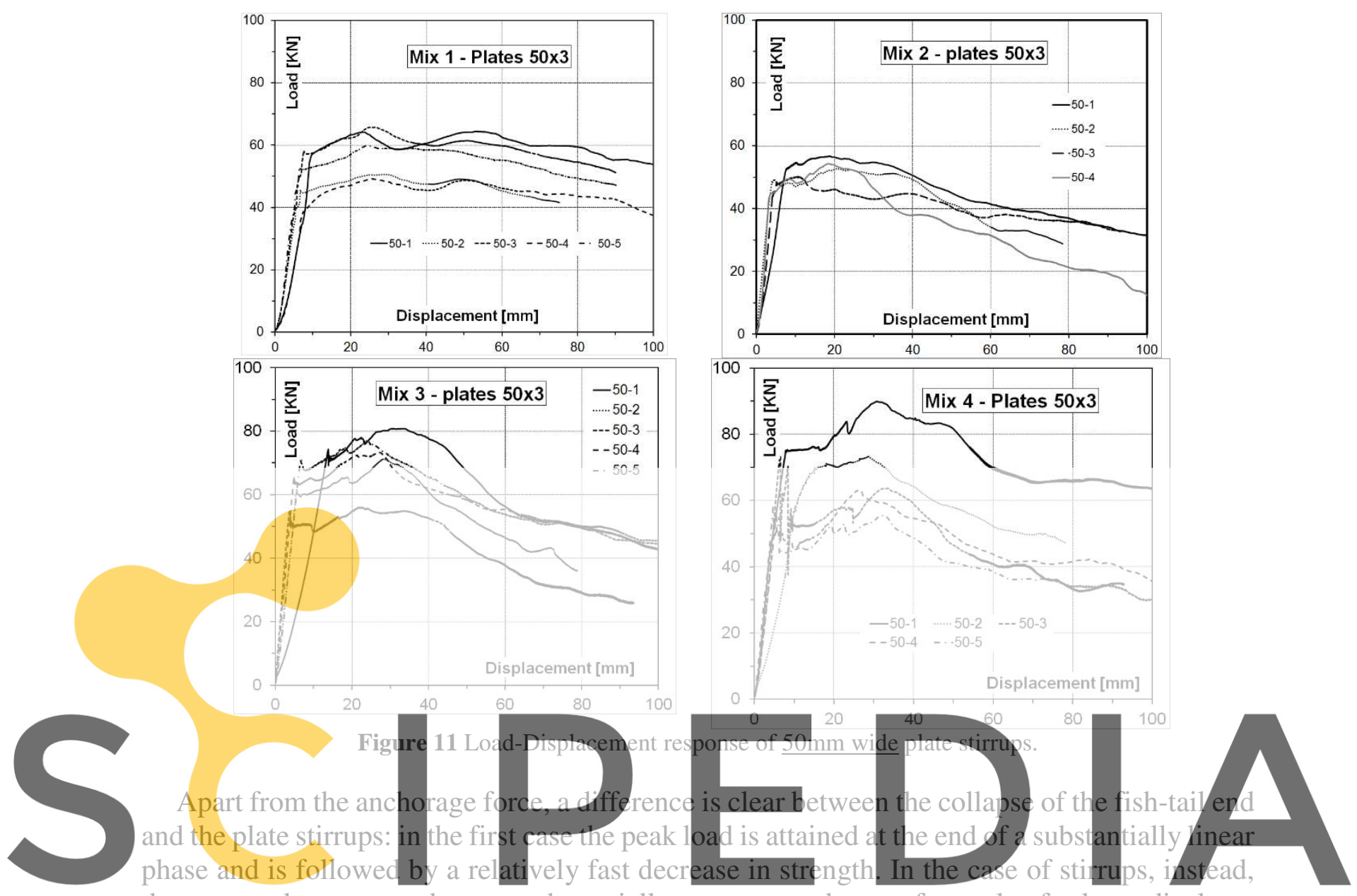

the post peak response shows a substantially constant anchorage force also for large displace-

Register for free at https//www.scipedia.com to download the version without the watermark We can also outline that the anchorage strength never induces in the bar a stress level close to yielding. This means that due to anchorage weakness, the steel elements used in the Hennebique System are unable of using their whole section.

\subsection{Collapse mechanism of the anchorage}

Figure 13 shows the fish-tail anchorage before (left) and after (right) the pull out test. It can be recognized that the fish-tail end has been shrank from twice the bar diameter to the bar dimeter for low strength concrete and to 0.75 the bar diameter for high strength concrete.

Figure 14 shows the concrete cube after the pull-out test of the bar. It is clear that the fishtails slide inside the cube producing a rather limited crushing zone just around its original position.

Figures 15 and 16 are related to the case of plate stirrups. It can be recognized that the collapse mechanism of the stirrup anchorage system almost does not involve concrete being limited to the rectification of the bended plates.

These mechanisms explain the main features of the diagrams of figure 9: fish-tail anchorage is shrank inside the concrete but this asks come concrete crushing to take place at the beginning of the pull-out test. For this reason, the anchorage strength depends on the concrete strength 
and for this same reason, concrete crushing, the post peak response shows a clearly softening branch.

For plate stirrups, instead, being the collapse of the anchorage mainly due to the plate rectification, the anchorage strength is little dependant on the concrete strength.
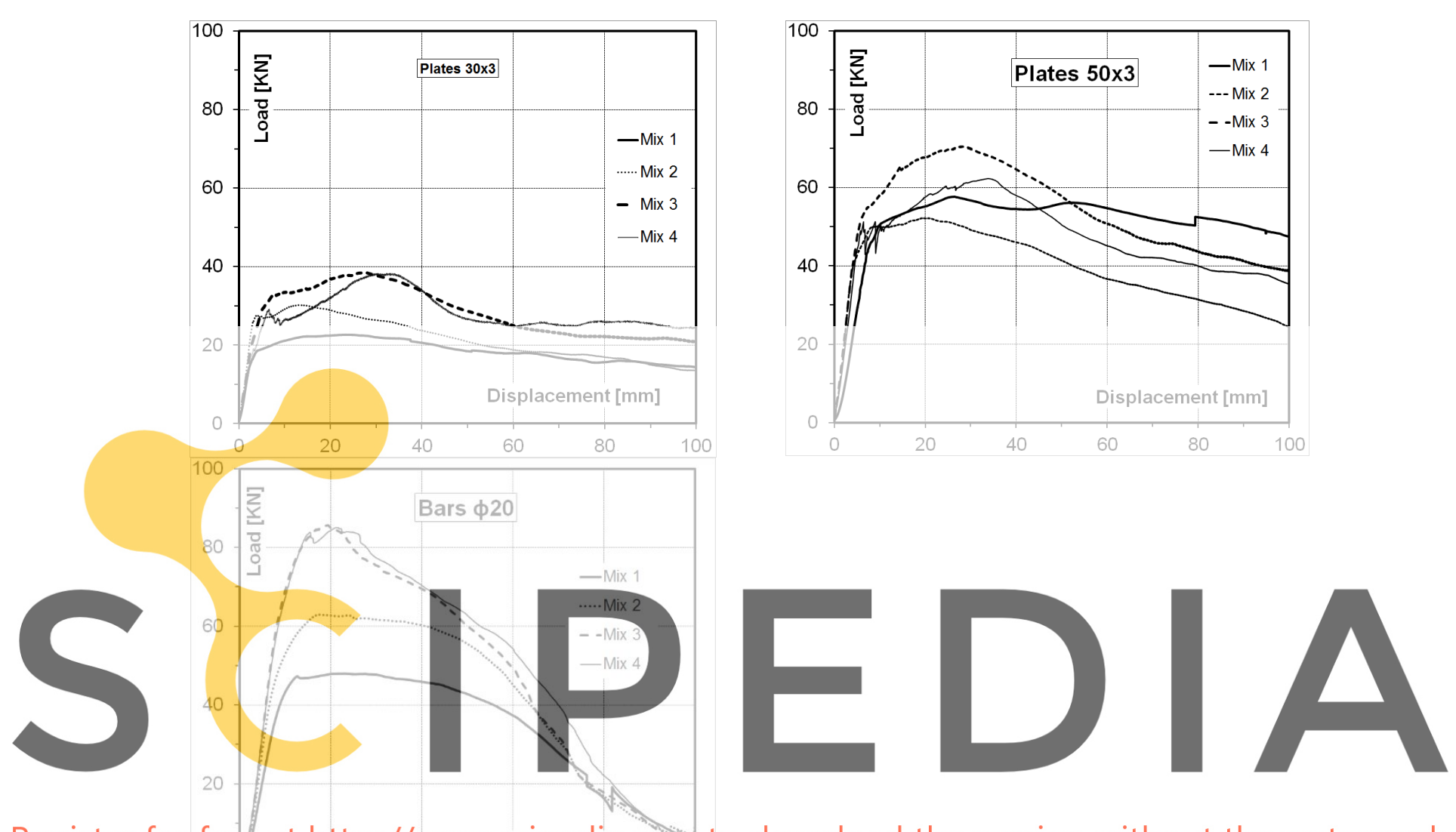

Register for free at https//WDiswaseripedia.COm to download the version without the watermark Figure 12 Load-Displacement response - average values
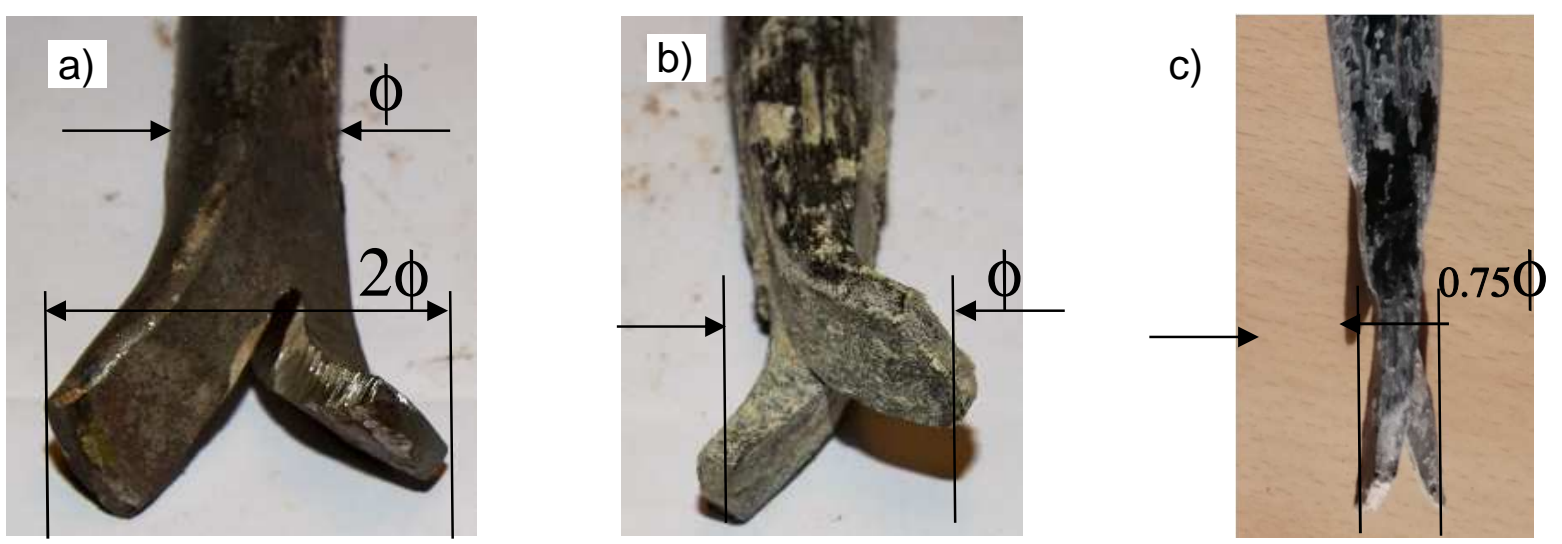

Figure 13: Fish-tail anchorage a) before and after the pull out test for b) low strength and c) high strength concrete. 

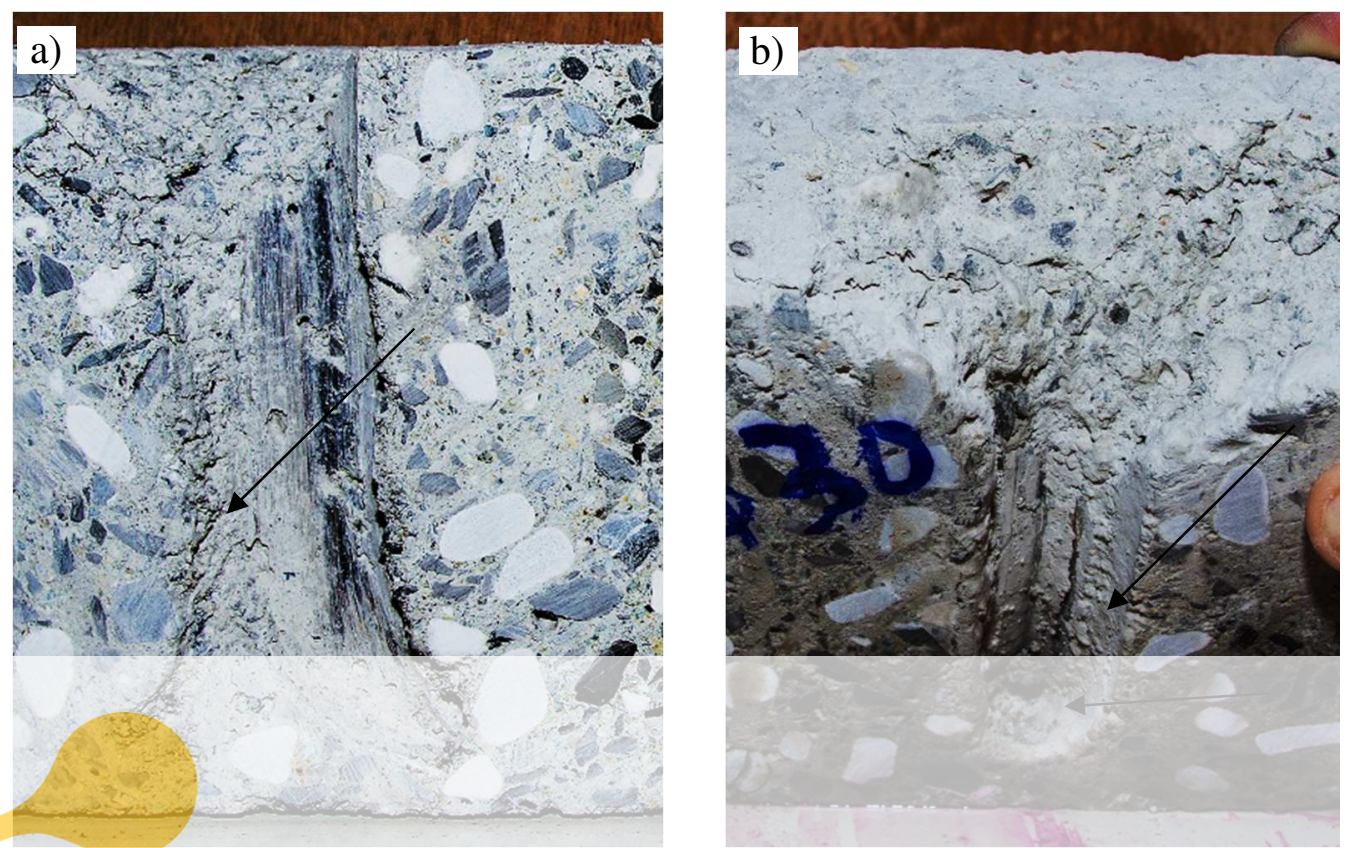

Figure 14: Track left in the concrete cube by the fish-tail anchorage. a) sliding of the bar along the steel/concrete interface; b) the central track (black arrows) show the sliding and the side crushing of the concrete due to the two tails

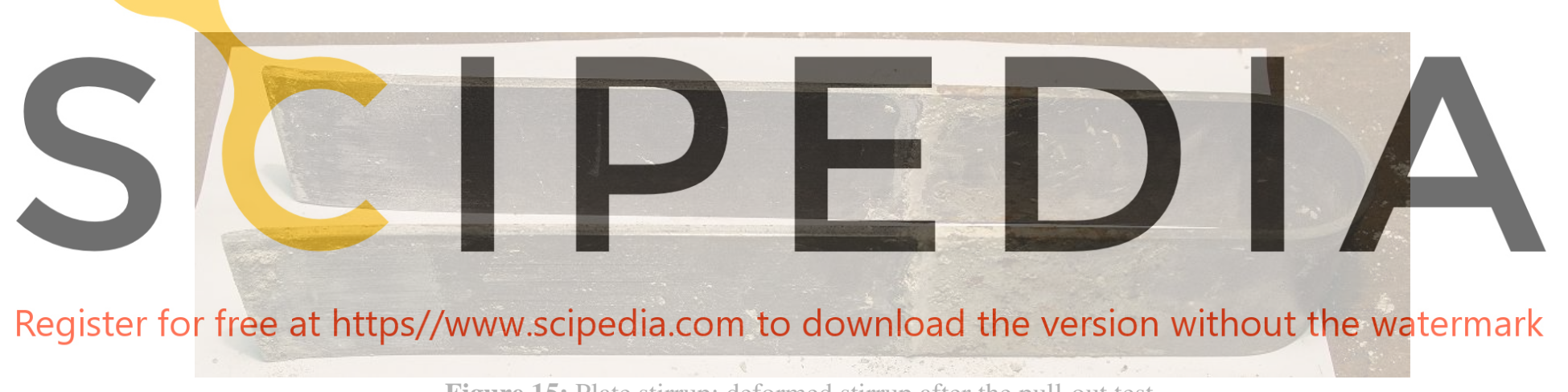

Figure 15: Plate stirrup: deformed stirrup after the pull-out test.

\section{CONCLUSIONS}

- Fish-tail ends. The strength of the anchorage never exceeds the force needed to close the fish-tails. The anchorage strength is approximately this value for medium and high strength concrete, but drops down to half this value in the rather common case of low strength concrete.

- Plate Stirrups. The collapse mechanism is that of rectification of the bended ends by sliding inside the concrete mass. It is not clear, at this point of the research, which could be a reference value for the anchorage.

- In both the test series, a biaxial confining stress state has been applied $\left(0.75 \mathrm{~N} / \mathrm{mm}^{2}\right)$. This transversal stress field is the best condition for this kind of anchorage. In case the lateral confinement is not biaxial and/or with lower stresses, the anchorage efficiency is expected to be lower. Further research is needed on this issue. 


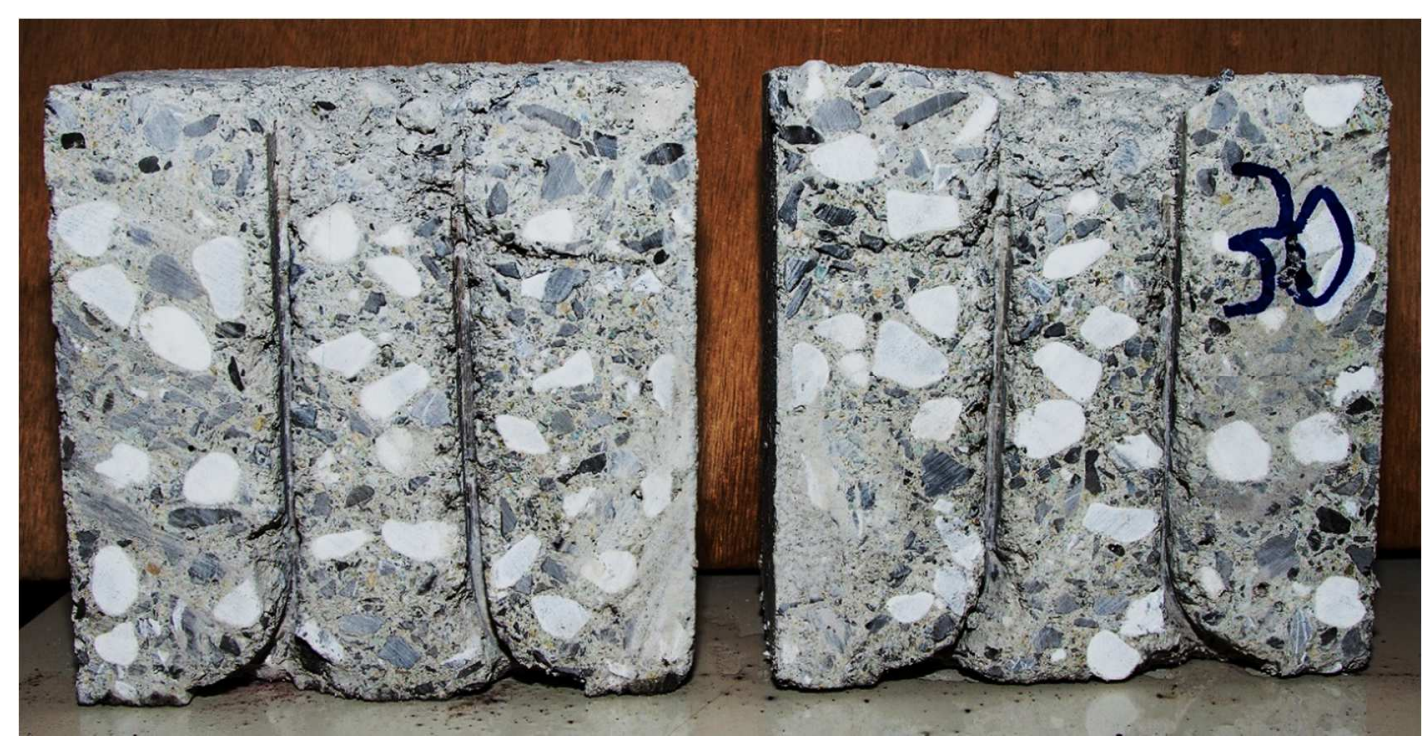

Figure 16: Track left in the concrete cube by the plate stirrup. It is clear that almost no concrete crushing takes place around the stirrup.

Acknowledgements. This research has been developed by means of internal resources only, which means that no funding was given by any public or private company. The authors acknowledge the contribution of the technical staff of the Civil Engineering Laboratory of the University of Genoa, among which S. Russo, G. Cassini, G. Riotto, D. Burlando and G. Tarantino.

\section{REFERENCES}

[1] Cusack P. François Hennebique: The Specialist Organisation and the Success of Ferro-Concrete: 1892-1909, Trans. of the Newcomen Soc., 56:1, 1984, 71-86.

[2] Mc Beth D.G. François Hennebique (1842-1921), reinforced concrete pioneer, Proc. Inst. Civ. Eng.s, 126 May, 1998, 86-95

[3] Delhumeau G. L'invention du béton armé : Hennebique 1890-1914, Norma, Paris, 1999

[4] Hellebois A. Theoretical and experimental studies on early reinforced concrete structures. Contribution to the analysis of the bearing capacity of the Hennebique system, Ph.D. Thesis, Ecole Polytechnique de Bruxelles, 2013.

[5] Cusack P. Agents of change: Hennebique, Mouchel, and ferro-concrete in Britain, 1897-1908. Construction History 3, 1987, 61-74.

[6] Borden A.H. Identifying early reinforced concrete buildings in Scotland. Proc. Inst. Civ. Eng.s Eng. History and Heritage 163 (3), 2010, 147-167.

[7] Hellebois A and Espion B. Domination of commercial patents in the evolution of early reinforced concrete. Case study of the region of Brussels. Proc. $7^{\text {th }}$ Int. Conf. on Str. Anal. of Historic Constr.s: Strengthening and Retroffiting, 2010, Gu X \& Song X ed.s. - Adv. Mat.s Res., Shanghai, China, vol. 133, pp. 119-124.

[8] de Courcy J.W. The emergence of reinforced concrete, 1750-1910. The Str. Eng. 65 (9), 1987, 315322 
[9] Kierdorf A. Why Hennebique failed in Germany. Strategies and obstacles in the introduction of a new construction technology, Proc. $3^{\text {rd }}$ Int. Cong. On Constr. History, Cottbus, May 2009, Brandenburg University of Technology, K.H.Kurrer, Lorenz W. and Wetsk V. ed.s, NEUNPLUS1, Berlin.

[10] Marcos, I., San José, J.T., Cuadrado, J., (2014). The patents in the introduction of reinforced concrete in Spain: "Alhóndiga de Bilbao" case study (in Spanish). Informes de la Construcción, 66 (534), 2014,

[11] Ragot G. The Hennebique Archives: toward a new corpus for contemporary architectural history. The American Archivist, 59 (2), 1996, 214-220.

[12] Nelva R., Signorelli B. Beginning and evolution of reinforced concrete in Italy: the Hennebique system (in Italian), AITEC, Milan, 1990

[13] Sanna A., First applications of reinforced concrete in Sardinia. The "Porcheddu Company Engineering S.A." and his plan archives. Proc. $1^{\text {st }}$ Int. Congr. on Constr. History, 2003, Huerta S., de Herrera I.J., Benvenuto E., Dragados F., 1809-1820.

[14] Iori T., Reinforced Concrete in Italy (in Italian), Edilstampa, Rome, 2001.

[15] Guidi C., Constructions in Beton Armeé (in Italian), appendix to Lessons on Structural Mechanics, Bona ed. Turin, 1907.

[16] Souponitski S.Z., Sniatkov S.V., Grigoriev S.E. Early reinforced concrete construction in Russia: specific faults and causes of failure, Eng. Fail. Anal., 8, 2001, 201-212.

[17] Mueller G., Rankin G.I.B. The Hennebique system: a Renaissance? Proc. of the Inst. of Civ. Eng.s, 90 (1), 1991, 179-187.

[18] Hellebois A., Launoy A., Pierre C., De Lanève M., Espion B. 100-year-old Hennebique concrete, from composition to performance, Constr. \& Build. Mat.s, 44, 2013, 149-160.

[19] Hellebois A., Espion B. Structural weaknesses of the Hennebique early reinforced concrete system and possible retrofitting. Str. Eng.ng Int., 23(4), 2013, 501-511

[20] Hellebois A., Espion B. Tests up to failure of a reinforced concrete Hennebique T-beam, Proc. of the Inst. of Civ. Eng.s - Structures and Buildings, 167 (2), 2014, 81-93.

[21] Foti D. Shear vulnerability of historical reinforced-concrete structures. Int. J. of Arch. Her., 9(4), 2015, 453-467.

[22] Palmisano F. A preliminary study on shear capacity of historical reinforced concrete beams, Int. J. of Her. Arch., 1 (4), 2017, 608-623.

[23] Christophe P. Reinforced Concrete and its applications (in French), Paris, Beranger ed., 1902

[24] The Porcheddu Document and Photographic Archive, Technical University of Turin, Dept. of Structural, Geotechnical and Building Eng.ng.

[25] Panetti M., Swiss issues on reinforced concrete constructions (in Italian), Civil Engineering and Industrial Arts, XXVIII (17), Bertolero ed.s, Turin, 1902.

[26] Gotelli R. (1915) Doubling Genova Brignole - Quarto dei Mille with deviation to Sturla, Italian Railways, work area, special office for doubling the line Genova-Spezia, Italian Railways ed., 1915

[27] Hennebique U.S. patent n. 611907, $4^{\text {th }}$ of October 1898.

[28] Porcheddu Archive, Dossier Genova, 1897, n. 38/1506, Oriental Market

[29] Porcheddu Archive - Dossier Genova 1896, n. 15/879, Giant Palace

[30] W.B. Fuller, S.E. Thompson, The laws of proportioning concrete, Trans. ASCE 59, (1907) 67-143.

[31] EN 1992-1-1:2004/A1:2014 - EuroCode 2 - Desing of Concrete Structures. General rules and rules for buildings.

[32] ASTM C192/C192M-18 Standard Practice for Making and Curing Concrete Test Specimens in the Laboratory

[33] EN 12390-2: 2019 Testing hardened concrete. Part 2: Making and curing specimens for strength tests 